\title{
Large virus-like particles from vacuoles of phaeodarian radiolarians and from other marine samples
}

\author{
Marcia M. Gowing \\ Institute of Marine Sciences, University of California, Santa Cruz, California 95064, USA
}

\begin{abstract}
Large icosahedral virus-like particles (LVLPS) ranging in diameter from ca 300 to $750 \mathrm{~nm}$ occurred in food or waste vacuoles of phaeodarian radiolarians collected in the Pacific Ocean, the Sargasso Sea and the Weddell Sea. The samples were from coastal to open-ocean waters, surface waters to $2000 \mathrm{~m}$ depth, and a variety of seasons. A few LVLPs were also found in bulk sediment trap material, in zooplankton guts and fecal pellets, and in minipellets. Phaeodarians are unique among small marine organisms because they carry a record of their past feeding activity within their phaeodium, a collection of food and waste vacuoles. This probably explains why they often contain abundant LVLPs. Phaeodarians appeared to have acquired the LVLPs while feeding on sinking or suspended particulate material. Calculations based on serial sections indicate that a single phaeodarian could contain thousands of LVLPs. Although their hosts have not been determined, LVLPs are clearly ubiquitous. These particles are being called LVLPs because of similarities in morphology with viruses, but they could be as yet unidentified microorganisms, a type of spore, or possibly an organelle of a eukaryote.
\end{abstract}

\section{INTRODUCTION}

Studies of natural populations of marine viruses have indicated that most viruses are small (heads $<60 \mathrm{~nm}$ ) and are probably bacteriophages (Bergh et al. 1989, Borsheim et al. 1990, Bratbak et al. 1990, 1992a, Proctor \& Fuhrman 1990, Wommack et al. 1992). However, Bratbak et al. (1992a) reported unusually large viruslike particles (VLPs) with heads 340 to $400 \mathrm{~nm}$ and tails 2.2 to $2.8 \mu \mathrm{m}$ long from Norwegian and Danish coastal waters. They were unable to determine the hosts. Because the large VLPs were present in a sample from a mesocosm experiment containing only planktonic organisms, they suggested that the host might be planktonic. They noted that some of the methods typically used for the study of marine viruses would either eliminate this size class from samples (prefiltration) or cause large VLPs to be counted as bacteria (epifluorescence microscopy).

The presence of similar large VLPs (LVLPs) has been noted intermittently in a variety of sediment trap and plankton samples since the early 1980s (Gowing \&
Silver unpubl.). The LVLPs have consistently occurred in vacuoles of phaeodarian radiolarians. Phaeodarians are sarcodines and engulf particles with pseudopodia. These omnivorous generalists appear to act as samplers of particulate material in their surroundings as they feed. They feed on detritus and a variety of cells ranging in size from bacteria to small metazoans, including microalgae and protozoans (Gowing 1986, Swanberg et al. 1986, Gowing 1989, Nöthig \& Gowing 1991, Gowing \& Garrison 1992). Their vacuoles typically contain siliceous debris such as pulverized diatom frustules. Because phaeodarians have no structures for grinding, siliceous fragments indicate feeding on sinking organic aggregates (Gowing 1989). Phaeodarians are unique in their accumulation of large numbers of food and waste vacuoles in what is collectively known as the phaeodium. The vacuoles are similar in size and content to the abundant minipellets in the ocean (Gowing \& Silver 1985). How long the vacuoles are retained within the organism is unknown; the time could be days to weeks. In a recent data set of phaeodarian vacuole contents analyzed for a feeding study, 
LVLPs were found in kigh abundances, and appeared to be similar to those described by Bratbak et al. (1992a). The purpose of this paper is to characterize LVLPs (greater than about $300 \mathrm{~nm}$ in the longest head dimension) both in phaeodarian vacuoles and in a variety of other marine samples, and to discuss the implications of their presence in these samples.

\section{MATERIALS AND METHODS}

Sample collection and fixation. The details of the collections are listed in Table 1 , and only the important features are summarized here. Sinking particulate material and organisms were collected from the upper $2000 \mathrm{~m}$ of the north Pacific Ocean as part of the multidisciplinary VERTEX project (see Martin et al. 1987 for a description of the overall project). Multitrap particle interceptor traps (Knauer et al. 1979) contained a borate-buffered paraformaldehyde or glutaraldehyde fixative in a sucrose density gradient (Gowing \& Silver 1983), and sinking material was collected over approximately 2 to $4 \mathrm{wk}$ periods at several locations once a year from 1980 to 1984 and seasonally at 1 location from 1986 to 1988. Austral fall and winter plankton tows and water samples from the Antarctic and tows from Monterey Bay, California, USA, were preserved with $0.1 \mathrm{M}$ cacodylate-buffered modified Karnovsky's fixative. Plankton tows from the Antarctic in the late austral winter were preserved with $2 \%$ formalin buffered with hexamine; tows from the Sargasso Sea were preserved with borate-buffered formalin. Copepods collected with the DSRV 'Alvin' were preserved in situ with glutaraldehyde.

Electron microscopy. Bulk trap material was centrifuged and enrobed in agar prior to processing for transmission electron microscopy (TEM). Details of processing of the various samples are given in the references in Table 1. Briefly, specimens or samples were rinsed in cacodylate buffer, postfixed in $1 \%$ osmium tetroxide in buffer, rinsed in buffer, dehydrated in a graded acetone series, and embedded in Spurr's or Poly Bed/Araldite resin. Thin sections were cut with a diamond knife, collected on polyvinyl formate (Formvar)-coated grids, stained with uranyl acetate and lead citrate, coated with carbon, and viewed with a JEOL $100 \mathrm{~B}$ transmission electron microscope at $80 \mathrm{kV}$. For all except 1 phaeodarian radiolarian, 2 grids of thin sections were examined from an area of the organism where there were 10 to 20 food and waste vacuoles. Nine grids of thin sections collected at $5 \mu \mathrm{m}$ intervals were examined from 1 specimen of Euphysetta leucani from the Sargasso Sea that had been serially sectioned with $1 \mu \mathrm{m}$ sections. The number of LVLPs in the entire phaeodarian (whose diameter was $137 \mu \mathrm{m}$ ) was cal- culated by multiplying the mean number of LVLPS per thin section by the volume of the phaeodarian available for vacuoles. The latter was calculated as 0.75 (total volume - nuclear volume); 0.75 is a conservative estimate of the volume of cytoplasm plus vacuoles that consisted of vacuoles.

Analysis of samples. Phaeodarian radiolarians from traps collected from 1986 to 1988 and from Antarctic plankton tows and copepods collected with the submersible 'Alvin' had originally been analyzed with TEM in sufficient detail that abundances of LVLPs were recorded. Phaeodarians that contained 6 or more LVLPS in thin sections (11 specimens) were re-examined for the presence of LVLPs in their nucleus and cytoplasm. Vacuole contents of the phaeodarians from the VERTEX VI cruises had been analyzed in detail for a feeding study (Gowing \& Bentham unpubl.); contents of vacuoles with and without LVLPs were compared.

Other samples, such as the trap material and some of the fecal pellets, had only been documented with random micrographs or had been studied in less detail, therefore there is considerably less information about these samples than about the phaeodarians and copepods. For the trap and pellet samples, records, including notebook entries (Gowing unpubl.) and approximately 8000 micrographs (Gowing \& Silver unpubl.) were examined for LVLPS.

LVLPs in micrographs from all samples were measured and their morphologies were recorded. There was no information on size or morphology from notebook entries for which micrographs had not been taken. The amount of DNA inside the head of a LVLP $600 \mathrm{~nm}$ in diameter was estimated from the head volume by a calculation based on the assumption that the packing of DNA was the same as that in the Chlorella virus PBCV-1 (190 nm diameter, genome size 333 kilobase pairs (kbp); Van Etten et al. 1991).

\section{RESULTS}

A total of 137 TEM micrographs of LVLPs from a variety of organisms and samples were examined Regardless of the fixative used, the LVLPs looked similar. Typical-sized virus-like particles (not enumerated) were present in some of the same samples, indicating that the processing of samples preserved the ultrastructure of other virus-like particles. A variety of morphologies were observed (Figs. 1 \& 2). The most common morphology was hexagonal; hexagonal and pentagonal cross-sections result from sections of icosahedrons, depending on the plane of the cut (e.g. Mattern et al. 1974). Sizes ranged from 298 to $750 \mathrm{~nm}$ in the longest diameter (Fig. 3). The widths of the visible tails ranged from 30 to $100 \mathrm{~nm}$; tail lengths are probably not 
Table 1. Locations, dates and depths of collections and literature sources for fixation and handling of samples

\begin{tabular}{|c|c|c|c|c|}
\hline Cruise & Location & Date & Collections & Source \\
\hline VERTEX I & $\begin{array}{l}35.7^{\circ} \mathrm{N}, 123.8^{\circ} \mathrm{W} \\
\mathrm{N} \text { Pacific } \\
\text { coastal upwelling }\end{array}$ & 26 Aug - 8 Sep 1980 & $\begin{array}{l}\text { Traps at } 12 \text { depths } \\
\text { from } 50 \text { to } 2000 \mathrm{~m}\end{array}$ & Silver et al. (1987) \\
\hline VERTEX II & $\begin{array}{l}18.0^{\circ} \mathrm{N}, 108.0^{\circ} \mathrm{W} \\
\text { E tropical Pacific }\end{array}$ & 27 Oct - 17 Nov 1981 & $\begin{array}{l}\text { Traps at } 9 \text { depths } \\
\text { from } 30 \text { to } 2000 \mathrm{~m}\end{array}$ & Gowing \& Silver (1985) \\
\hline VERTEX III & $\begin{array}{l}15.7^{\circ} \mathrm{N}, 107.5^{\circ} \mathrm{W} \\
\text { E tropical Pacific }\end{array}$ & $9-30$ Nov 1982 & $\begin{array}{l}\text { Traps at } 9 \text { depths } \\
\text { from } 80 \text { to } 2000 \mathrm{~m}\end{array}$ & $\begin{array}{l}\text { Gowing \& Silver (1985) } \\
\text { Silver \& Gowing (1991) }\end{array}$ \\
\hline VERTEX IV & $\begin{array}{l}28.0^{\circ} \mathrm{N}, 155.0^{\circ} \mathrm{W} \\
\mathrm{N} \mathrm{Pacific} \mathrm{central} \\
\text { gyre }\end{array}$ & $21 \mathrm{Jul}-23$ Aug 1983 & $\begin{array}{l}\text { Traps at } 10 \text { depths } \\
\text { from } 50 \text { to } 2000 \mathrm{~m}\end{array}$ & Gowing (1986) \\
\hline VERTEX VA & $\begin{array}{l}33.3^{\circ} \mathrm{N}, 139.2^{\circ} \mathrm{W} \\
\text { N Pacific } \\
\text { gyre edge }\end{array}$ & 8-29 June 1984 & $\begin{array}{l}\text { Traps at } 7 \text { depths } \\
\text { from } 150 \text { to } 2000 \mathrm{~m}\end{array}$ & Gowing \& Coale (1989) \\
\hline $\begin{array}{l}\text { VERTEX VI-1 } \\
\text { VERTEX VI-2 } \\
\text { VERTEX VI-4 } \\
\text { VERTEX VI-5 } \\
\text { VERTEX VI-6 }\end{array}$ & $\begin{array}{l}33^{\circ} \mathrm{N}, 139^{\circ} \mathrm{W} \\
\mathrm{N} \text { Pacific gyre } \\
\text { edge }\end{array}$ & $\begin{array}{l}29 \text { Oct } 1986-22 \text { Jan } 1987 \\
26 \text { Jan }-9 \text { May } 1987 \\
14 \text { Jul }-22 \text { Oct } 1987 \\
27 \text { Oct } 1987-30 \text { Jan } 1988 \\
3 \text { Feb - } 6 \text { May } 1988\end{array}$ & $\begin{array}{l}\text { Traps at } 10-12 \text { depths } \\
\text { from } 50 \text { to } 2000 \mathrm{~m}\end{array}$ & Gowing (1993) \\
\hline AMERIEZ 86 & $\begin{array}{l}65-66^{\circ} \mathrm{S}, 42-50^{\circ} \mathrm{W} \\
\text { Weddell Sea }\end{array}$ & Mar 1986 & $\begin{array}{l}\text { Tows in upper } 200 \mathrm{~m} \\
\text { Water sample at } 600 \mathrm{~m}\end{array}$ & Gowing (1989) \\
\hline AMERIEZ 88 & $\begin{array}{l}57-62^{\circ} \mathrm{S}, 35-50^{\circ} \mathrm{W} \\
\text { Weddell/Scotia Seas }\end{array}$ & 9 Jun - 13 Aug 1988 & $\begin{array}{l}\text { Water samples in } \\
\text { upper } 200 \mathrm{~m}\end{array}$ & Gowing \& Garrison (1992) \\
\hline WWGS 89 & $\begin{array}{l}65-75^{\circ} \mathrm{S}, 8-45^{\circ} \mathrm{W} \\
\text { Weddell Sea }\end{array}$ & 16 Sep - 13 Oct 1989 & Tows to $1000 \mathrm{~m}$ & Nöthig \& Gowing (1991) \\
\hline 'Alvin' SCB & $\begin{array}{l}33^{\circ} 13.8^{\prime} \mathrm{N}, 118^{\circ} 36.3^{\prime} \mathrm{W} \\
\text { Santa Catalina Basin }\end{array}$ & 4-11 Dec 1984 & $\begin{array}{l}\text { Tows at } 1250 \\
\text { and } 1300 \mathrm{~m}\end{array}$ & Gowing \& Wishner (1986) \\
\hline 'Alvin' V7 & $\begin{array}{l}13^{\circ} 23^{\prime} \mathrm{N}, 102^{\circ} 27^{\prime} \mathrm{W} \\
\text { E tropical Pacific } \\
\text { seamount }\end{array}$ & 23 Nov - 4 Dec 1988 & $\begin{array}{l}\text { Tows at } 750,1300 \\
\text { and } 3100 \mathrm{~m}\end{array}$ & Gowing \& Wishner (1992) \\
\hline BATS & $\begin{array}{l}31.2^{\circ} \mathrm{N}, 64.5^{\circ} \mathrm{W} \\
\text { Sargasso Sea }\end{array}$ & 9 Aug 1991 & Surface tow & See 'Methods' \\
\hline MB 92,93 & $\begin{array}{l}36^{\circ} 45.7^{\prime} \mathrm{N}, 121^{\circ} 57.1^{\prime} \mathrm{W} \\
\text { Monterey Bay, CA, USA }\end{array}$ & $\begin{array}{l}10 \text { Mar } 1992 \\
27 \text { Feb } 1993\end{array}$ & $0-100 \mathrm{~m}$ tow & See 'Methods' \\
\hline
\end{tabular}

meaningful because the whole length may not have appeared in a section. The majority of LVLPs had electron-dense material in the head; some of this material appeared to be a continuation of a tail (Fig. $1 \mathrm{~J}$ to $\mathrm{L}$, $\mathrm{N}, \mathrm{O}$ ). Occasional empty heads were seen (Fig. 2A). The boundary of the LVLPs appeared multi-layered, with the distance from the innermost to outermost layer ca $30 \mathrm{~nm}$ and the distance between adjacent electron-dense layers ca $15 \mathrm{~nm}$; occasionally there was material beyond the outermost layer (Fig. 1D, H, N, O). If the material in the heads is DNA, a head $600 \mathrm{~nm}$ in diameter could contain up to about $1.05 \times 10^{4} \mathrm{kbp}$, $6.54 \times 10^{9} \mathrm{Da}$, or $0.01 \mathrm{pg}$ of DNA.

LVLPS were ubiquitous in the samples, occurring in vacuoles of several species of phaeodarian radiolarians collected from surface waters to $2000 \mathrm{~m}$ in coastal and open ocean regions around the world during several seasons (Tables 2 \& 3). On the VERTEX VI cruises, LVLPs were found in vacuoles of 7 species of phaeodarian radiolarians collected during 5 seasons from surface waters to $2000 \mathrm{~m}$ at the edge of the north Pacific central gyre (Table 3). LVLPs were present in 

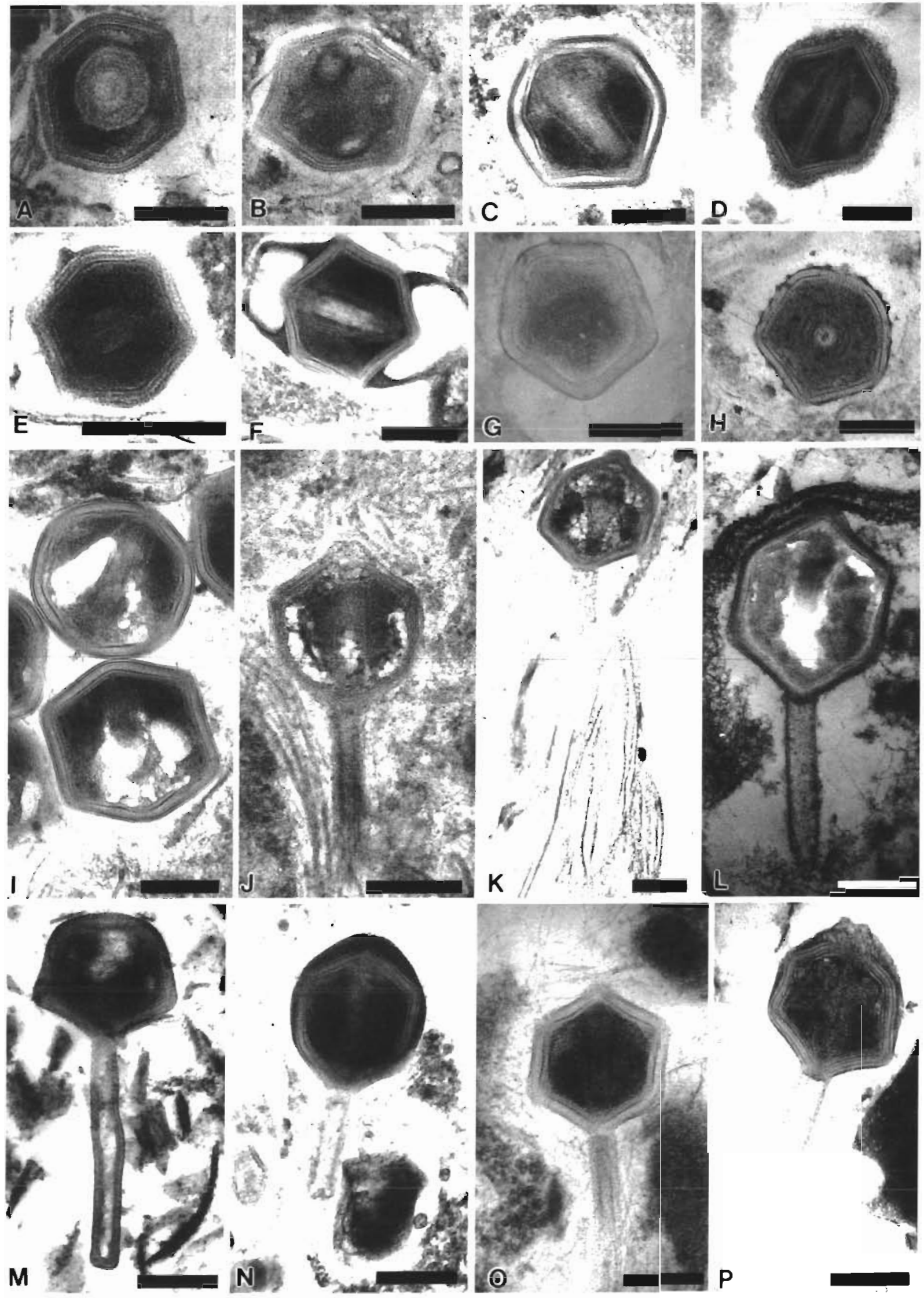
Fig. 1. Transmission electron micrographs of LVLPs. (A) LVLP from a vacuole of the phaeodarian Protocystis xiphodon collected at $200 \mathrm{~m}$ in the N Pacific in fall 1986. (B) LVLP from a vacuole of a Castanellid phaeodarian from the upper $100 \mathrm{~m}$ of Monterey Bay, California, USA, in March 1992. (C) LVLP from a vacuole of the phaeodarian Challengeron willemoesii from $400 \mathrm{~m}$ from the $\mathrm{N}$ Pacific from summer 1987. Note what could be a part of a tail in the center of the particle. (D) LVLP from a vacuole of the phaeodarian Euphysetta leucani from the surface waters of the Sargasso Sea in August 1991. Note what could be part of a tail in the center of the LVLP. (E) LVLP from a vacuole of the phaeodarian Challengerosium radians from $1500 \mathrm{~m}$ in the $\mathrm{N}$ Pacific in June 1984. (F) LVLP from a vacuole of C. willemoesii from $275 \mathrm{~m}$ in the N Pacific in June 1984 . This was the only LVLP observed with horn-like structures. (G) LVLP from a vacuole of the phaeodarian Euphysetta elegans from $2000 \mathrm{~m}$ in the $\mathrm{N}$ Pacific in spring 1988. (H) LVLP from a vacuole of the phaeodarian Challengerosium avicularia from $850 \mathrm{~m}$ in the $\mathrm{N}$ Pacific in summer 1987 (I) LVLPs from a vacuole of the phaeodarian Euphysetta pusilla from $250 \mathrm{~m}$ in the N Pacific in fall 1986. (J) LVLP from a vacuole of E. pusilla from $400 \mathrm{~m}$ in the N Pacific in spring 1987 (K) LVLP from a vacuole of E. elegans from $1500 \mathrm{~m}$ in the $\mathrm{N}$ Pacific in winter 1988. (L) LVLP from a vacuole of Porospathis sp. from 500 to $1000 \mathrm{~m}$ the Weddell Sea in the late austral winter 1989. (M) LVLP from the gut of an immature male copepod Xanthocalanus sp. from $1300 \mathrm{~m}$ in the Santa Catalina Basin in 1984. (N) LVLP from a vacuole of the phaeodarian Haeckeliana sp. from $1500 \mathrm{~m}$ in the N Pacific in June 1984. (O) LVLP from the vacuole of the phaeodarian Lirella melo from $550 \mathrm{~m}$ in the N Pacific in fall 1986. (P) LVLP from E. leucani from the surface waters of the Sargasso Sea in August 1991. All scale bars $=0.25 \mu \mathrm{m}$

$45 \%$ (of 184 specimens) of phaeodarians from this location and in 2 to $8 \%$ (of 181 specimens) from the 3 Antarctic locations. No LVLPs were ever found in the nucleus or cytoplasm. A comparison of contents of sections of vacuoles containing LVLPs and those lacking LVLPs showed that more bacteria, cyanobacteria, algal cells, and some cellular remnants occurred in vacuoles with LVLPs than in those lacking LVLPs (Table 4). Amorphous material was also more prevalent in vacuoles containing LVLPs, but siliceous debris was slightly more prevalent in vacuoles lacking LVLPs. No LVLPs were seen inside any of the recognizable cells in food vacuoles.

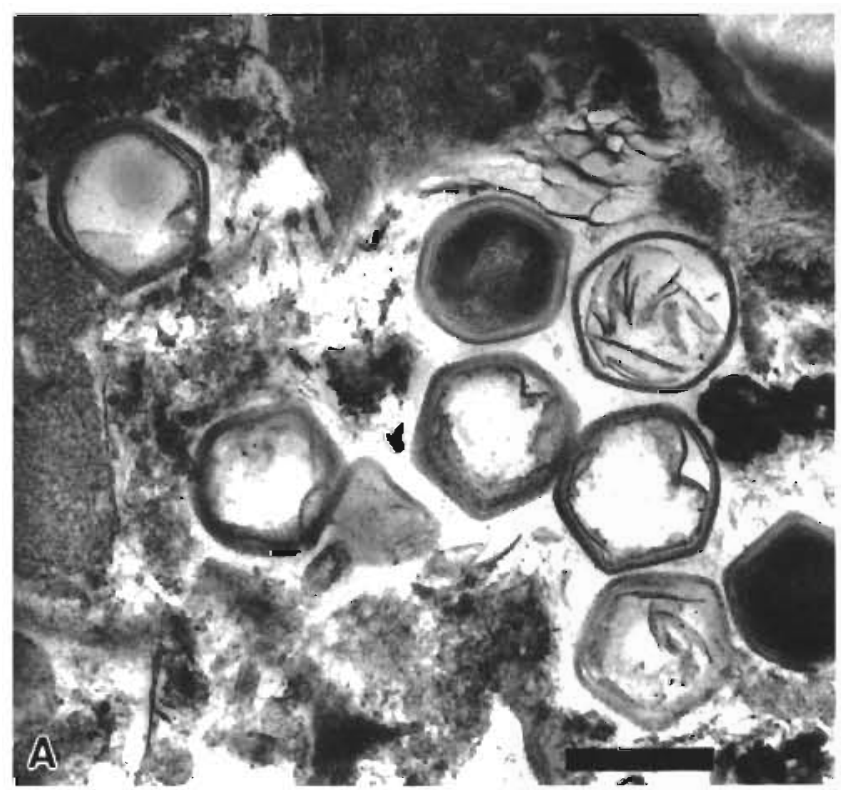

LVLPs were also observed in several other types of samples. These included bulk trap material from 100 and $700 \mathrm{~m}$ from VERTEX 1 and from $2000 \mathrm{~m}$ from VERTEX III. LVLPs were found in minipellets (e.g. Gowing \& Silver 1985) from 120 and $400 \mathrm{~m}$ trap material from VERTEX II and $140 \mathrm{~m}$ trap material from VERTEX II. LVLPs occurred in a zooplankton fecal pellet from $700 \mathrm{~m}$ from VERTEX I, in zooplankton fecal pellets from 30 and $400 \mathrm{~m}$ and in a fecal pellet of the swimming crab Pleuroncodes planipes from $120 \mathrm{~m}$ from VERTEX II, and in a larvacean gut from $80 \mathrm{~m}$ from VERTEX I and larvacean guts from the Sargasso Sea plankton tow. Out of 91 'Alvin'-collected copepods

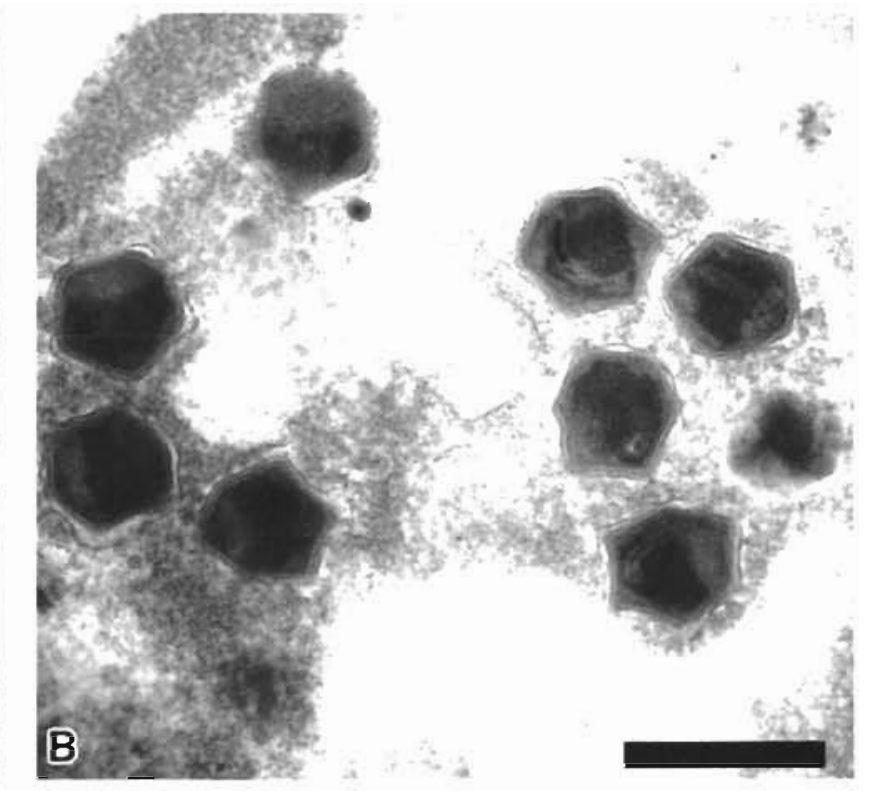

Fig. 2. Transmission electron micrographs of LVLPs. (A) LVLPs from a vacuole of the phaeodarian Protocystis tridens from $600 \mathrm{~m}$ in the Weddell Sea in the austral fall 1986. Note that several of the LVLPs are empty. (B) LVLPs in the food vacuole of the heliozoan Sticholonche sp. collected in the upper $200 \mathrm{~m}$ of the Weddell Sea during the austral winter 1988 . Scale bars $=0.5 \mu \mathrm{m}$ 


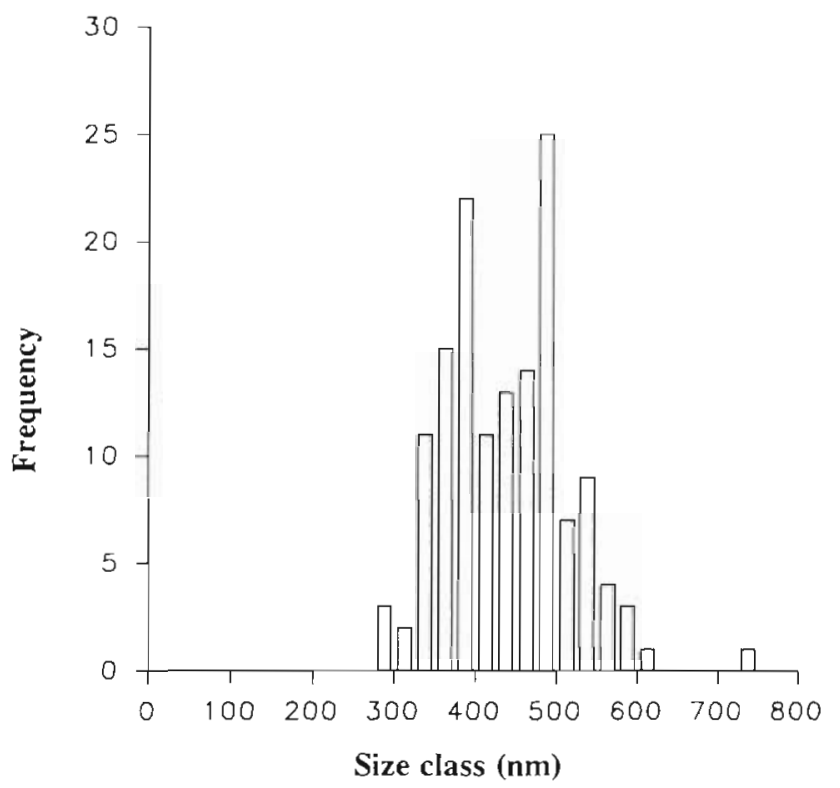

Fig. 3. Size-frequency plot of maximum diameters of individual heads of LVLPs. Measurements were divided into size classes $(1-25,26-50,51-75 \mathrm{~nm}$ etc. $)$; midpoints of the size classes are shown

Table 2. Occurrences of LVLPs in thin sections of vacuoles of phaeodarian radiolarians from particle interceptor traps and plankton tows. e: empty LVLPs. Months of sampling are in Table 1

\begin{tabular}{|c|c|c|c|}
\hline $\begin{array}{l}\text { Location } \\
\text { and date }\end{array}$ & $\begin{array}{l}\text { Depth } \\
\text { (m) }\end{array}$ & Number & Phaeodarian \\
\hline N Pacific, 1981 & 120 & 1 & Aulacantha scolymantha \\
\hline N Pacifc, 1982 & 80 & 1 & Unidentified \\
\hline N Pacific gyre, 1983 & $\begin{array}{r}150 \\
300 \\
1100\end{array}$ & $\begin{array}{l}1 \\
1 \\
2\end{array}$ & $\begin{array}{l}\text { Phaeodina sp. } \\
\text { Conchopsidae } \\
\text { Unidentified }\end{array}$ \\
\hline N Pacific, 1984 & $\begin{array}{r}275 \\
750 \\
1000 \\
1000 \\
1500 \\
1500 \\
1500\end{array}$ & $\begin{array}{l}1 \\
1 \\
3 \\
1 \\
1 \\
2 \\
1\end{array}$ & $\begin{array}{l}\text { Challengeron willemoesii } \\
\text { Protocystis sp. } \\
\text { Phaeodina sp. } \\
\text { C. willemoesii } \\
\text { Challengerosium radians } \\
\text { Haeckeliana sp. } \\
\text { Haeckeliana sp. }\end{array}$ \\
\hline Weddell Sea, 1986 & $\begin{array}{c}0-200 \\
600\end{array}$ & $\begin{array}{l}1,13 \mathrm{e} \\
2,5 \mathrm{e}\end{array}$ & $\begin{array}{l}\text { Cannosphaera antarctica } \\
\text { Protocystis tridens }\end{array}$ \\
\hline $\begin{array}{l}\text { Weddell/Scotia } \\
\text { Seas, } 1988\end{array}$ & $\begin{array}{l}0-200 \\
0-200\end{array}$ & $\begin{array}{l}1 \\
1\end{array}$ & $\begin{array}{l}\text { Challengeron swirei } \\
\text { Phaeodina antarctica }\end{array}$ \\
\hline Weddell Sea, 1989 & $500-1000$ & 1 & Porospathis sp. \\
\hline Sargasso Sea, 1991 & $\begin{array}{l}\text { Surface } \\
\text { Surface } \\
\text { Surface } \\
\text { Surface }\end{array}$ & $\begin{array}{c}1,10 \mathrm{e} \\
5 \\
4,2 \mathrm{e} \\
39^{\mp}, 1 \mathrm{e}\end{array}$ & $\begin{array}{l}\text { Euphysetta leucani } \\
\text { E. leucani } \\
\text { E. leucani } \\
\text { E. leucani }\end{array}$ \\
\hline Monterey Bay, 1992 & $0-100$ & 1 & Castanellidae \\
\hline Monterey Bay, 1993 & $0-100$ & 1 & Phaeodina valdiviae \\
\hline
\end{tabular}

from $1300 \mathrm{~m}$ in the Santa Catalina Basin, 1 LVLP was found in the gut of an immature male Xanthocalanus sp. and one in a minipellet in the gut of Diaixis sp. Out of 79 'Alvin'-collected copepods from the Volcano 7 seamount in the eastern tropical Pacific, 1 LVLP was found in a minipellet in the gut of a female Heterostylites longicornis from $752 \mathrm{~m}$ and 1 was found in the gut of Scolecithricella sp. from $1300 \mathrm{~m}$. Several LVLPs were found in a food vacuole of 1 specimen (of 13 specimens examined) of the heliozoan Sticholonche sp. from the upper $200 \mathrm{~m}$ of the Weddell Sea in the austral winter (Fig. 2B).

\section{DISCUSSION}

LVLPs were found in feeding structures of several different marine organisms from various oceans. The morphology of these particles is similar wherever they are found, and they have several features in common with viruses and virus-like particles depicted in the literature, as well as some differences. Icosahedrons are common shapes for bacterial, algal, and animal viruses (e.g. Bradley 1967, Tinsley \& Harrap 1978, Palmer \& Martin 1988, Van Etten et al. 1991). Some of the LVLPs look similar to published micrographs of known large viruses, for example, the iridoviruses (e.g. Fig. 1 of Devauchelle et al. 1985 , Fig. 21C of Doane \& Anderson 1987) and the African swine fever virus (Fig. 2 of Viñuela 1985). The African swine fever virus (diameter $200 \mathrm{~nm}$; Viñuela 1985) is smaller than the LVLPs, but iridoviruses (diameters of 120 to $380 \mathrm{~nm}$; Anthony \& Comps 1991) overlap in size with the LVLPs Iridoviruses include the erythrocytic necrosis viruses (150 to $400 \mathrm{~nm}$ ) of marine fish (Plumb 1993). Although Bratbak et al. (1992a) did not section their LVLPs, the shapes of some of the heads of the LVLPs observed in the present study (e.g. Fig. $1 \mathrm{~J}, \mathrm{~K}$ ) are consistent with their micrographs of negatively stained LVLPs. Some of the LVLPS with tails (e.g. Fig. 1N) resemble viruses of zoospores of the alga Chlorococcum minutum, although the heads of the latter were only $220 \times$ $180 \mathrm{~nm}$ (Gromov \& Mamkaeva 1981). Gromov \& Mamkaeva (1981) also remarked that the tail was often invaginated into the head of mature viruses; some of the rod-shaped inclu- 
Table 3. Total numbers of LVLPs observed in vacuoles of phaeodarians from the seasonal VERTEX VI cruises at the edge of the north Pacific central gyre. Number in parentheses: depth where phaeodarians were trapped. Fraction in brackets: number of phaeodarians containing LVLPs/total number of specimens of that species for all seasons combined

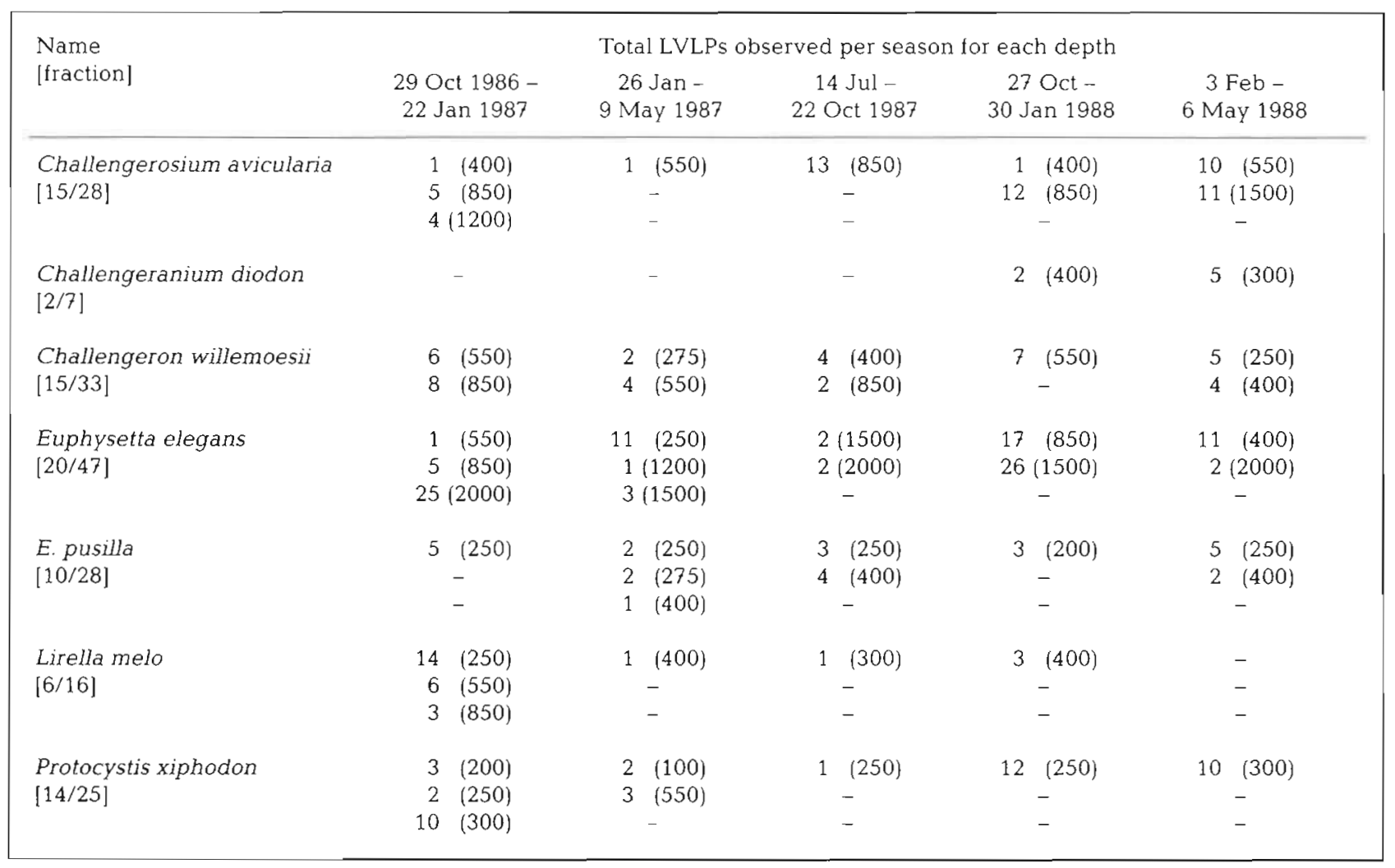

sions in the center of the LVLPs could be invaginated tails. The layers surrounding the cores of the LVLPs in the present study are distinctive and appear similar to but more complex than layers described for other algal VLPs. Hoffman \& Stanker (1976) noted that the 200 to $230 \mathrm{~nm}$ algal VLPs they studied had 'a well-developed, multilayered, membranous coat which is $14-16 \mathrm{~nm}$ thick' (p. 2829). The coats they describe are the thickness of 1 layer of the ones in the present study. The coats of the 200 to $230 \mathrm{~nm}$ algal VLPs studied by Swale \& Belcher (1973) were about $30 \mathrm{~nm}$ thick, with several dark and light laminations. The large (390 nm) VLPs infecting Uronema gigas had a $15 \mathrm{~nm}$ multilaminate shell (Dodds \& Cole 1980), and the large (380 to $400 \mathrm{~nm}$ ) VLPs infecting Brachiomonas sp. had a trilamellar coat (L. Hoffman pers. comm.). Eukaryotic algal viruses and VLPs typically have an external multilaminate shell surrounding the core (Dodds 1979, Van Etten et al. 1991), Morphological differences between the LVLPs and large algal VLPs could be due to differences in fixation and processing and the possibility that LVLPs in food vacuoles are partially digested. Furthermore, the large algal VLPs are from fresh water, so the LVLPs would not be expected to be identical to them.
Size is one important difference between the LVLPS described here and most published micrographs of viruses and virus-like particles. However, there are several examples in the literature of viruses and virus-

Table 4. Comparison of vacuole contents between vacuoles containing LVLPs and vacuoles lacking LVLPs. Percentages of vacuoles containing the various categories of cells, cell remnants, and detrital material are shown. Vol. = volume of vacuoles, assuming thin sections were $90 \mathrm{~nm}$ thick

\begin{tabular}{|lcc|}
\hline Category & $\begin{array}{c}\text { Vacuoles } \\
\text { with LVLPs } \\
\mathrm{n}=207 \text { vacuoles } \\
\text { Vol. }=1388 \mu \mathrm{m}^{3}\end{array}$ & $\begin{array}{c}\text { Vacuoles } \\
\text { lacking LVLPs } \\
\mathrm{n}=2827 \text { vacuoles } \\
\text { Vol. }=16029 \mu \mathrm{m}^{3}\end{array}$ \\
\hline Bacteria & 49 & 22 \\
Cyanobacteria & 6 & 3 \\
Algal scales & 5 & $<1$ \\
Algal cells & 11 & 8 \\
Chlorella-like cells & 7 & 4 \\
Trichocysts & $<1$ & 5 \\
Unidentified cell & 6 & 77 \\
Annorphous material & 94 & 20 \\
Siliceous debris & 17 & $<1$ \\
Unknown structure & 0 & \\
\hline
\end{tabular}


like particles that overlap the lower end of the size range of LVLPs. In addition to the aforementioned large VLPs described by Bratbak et al. (1992a) and some of the iridoviruses (Anthony \& Comps 1991), there are several reports of 'larger'-sized icosahedral (200 to $400 \mathrm{~nm}$ diameter) algal viruses and algal VLPs (reviewed by Sherman \& Brown 1978, Van Etten et al. 1991, and Reisser 1993).

Other differences between the LVLPs and known tailed viruses are the lack of obvious subunit structure in the tails of the LVLPS (L. Proctor pers. comm., L. Hoffman pers. comm.) and the occurrence of a membrane-like structure within the head of Fig. 1D (F. Eiserling pers. comm.). Of the 4 reports of tailed, non-Chlorella eukaryotic algal viruses and VLPS (reviewed by Van Etten et al. 1991), 2 of the VLPs had a distinctive tail substructure. The tails of the VLPs infecting Brachiomonas sp. had a collar on their proximal end and were striated at ca $11 \mathrm{~nm}$ intervals (L. Hoffman pers. comm.). These VLPS also had an internal 'rod-shaped' core in the head when the tail was not present (L. Hoffman pers. comm.). The collar-less, hollow cylindrical tails of the VLPs infecting Aulacomonas sp. showed 'conspicuous alternating rows of dark subunits $7 \mathrm{~nm}$ across and apart' (Swale \& Belcher 1973 . p. 100). In contrast, the tails of the VLPs infecting Chlorococcum minutum lacked collars (Gromov \& Mamkaeva 1981), and micrographs showed no repetitive substructure. The tails of the large $1390 \mathrm{~nm}$ head diameter) VLPs infecting Uronema gigas had a distinctive midpoint swelling (Dodds \& Cole 1980); a repetitive substructure could not be ruled out (J. A. Dodds pers. comm.). Thus the tails of the few known tailed large VLPs of eukaryotic algae appear to be morphologically diverse, compared to tails of bacteriophages. Reanney \& Ackermann (1982), in their review of evolution of bacteriophages, state that 'the Uronema and Chlorococcum particles probably represent new virus categories, but their resemblance to phages is superficial and their tail seems to be a response to the unicellular nature of the host' (p. 260). This may also apply to the tailed LVLPs reported here.

The different morphologies of LVLPS may also represent stages in the life cycle of something other than a virus (L. Proctor pers. comm.), and they could also represent a variety of entities, some of which may be viruses and others not. Other possible identities of these particles include: an as yet undescribed microorganism, some type of spore, or organelles or gametes of eukaryotes. Although of a similar size to bacterial spores, the LVLPS otherwise differ from known spores such as those of the non-marine bacterium Bacillus cereus. Spores of $B$. cereus are typically found in a nutrient-poor environment, possess a cortex, and are usually found in the presence of rods, and as endospores (A. Aronson pers. comm.). The ultrastructure of the LVLPs also differs from that of spores of several species of Clostridium (e.g. Takagi et al. 1960, Pope \& Rode 1969). Unfortunately, there are few data on marine spore-forming bacteria from the open ocean (Sieburth 1979). The estimate of the DNA content of the LVLPs falls within the range of DNA content reported for bacteria $\left(0.1\right.$ to $8 \times 10^{9} \mathrm{Da}_{i}$ Herdman 1985) and fungi (0.009 to $1.5 \mathrm{pg}$; Cavalier-Smith 1985). A similar calculation suggests that the LVLPs are unlikely to be gametes of eukaryotes. With the exception of Saccharomyces cerevisiae $(0.009$ pg; CavalierSmith 1985), DNA content of haploid cells of eukaryotes typically exceeds $0.05 \mathrm{pg}$ and is often an order of magnitude or more larger (reviewed by Hinegardner 1976 and Cavalier-Smith 1985). With an estimated $0.01 \mathrm{pg}$ of DNA, the LVLPs appear to contain too little DNA for the eukaryotic genome. In summary, the particles are presently referred to as virus-like, and molecular or classical (transfer of infection) proof or disproof is needed

The common presence of the LVLPs in food vacuoles of phaeodarian radiolarians raises the question of how the particles were acquired. The phaeodarians could have sustained a viral infection or engulfed the LVLPS during feeding. It seems unlikely that the phaeodarians themselves were infected because no LVLPs were observed in either their cytoplasm or nucleus, and nuclear and cytoplasmic morphology were normal. Cells with visible viral or presumed viral infections typically have large numbers of VLPs in these regions and often, but not always, appear moribund (e.g Dodds 1979, Doane \& Anderson 1987). Thus the LVLPs were probably acquired during feeding. The LVLPs could have entered with organisms or particulate material consumed. A few instances were observed where there were several LVLPs in a section through a vacuole, which would be consistent with entry inside an infected cell. However, there was no indication, such as recognizable cell remnants, as to what the cell may have been. Furthermore, none of the sections through intact cells in vacuoles contained LVLPs.

The comparison of contents of vacuoles with and without LVLPs suggests that vacuoles with LVLPs are more likely to contain also intact cells such as bacteria, cyanobacteria, Chlorella-like cells, and other small cells. This suggests that the LVLPs could somehow be associated with one of these types of cells. Because the LVLPs are so large, they are unlikely to be bacteriophages or cyanophages (e.g. Sherman \& Brown 1978 , Frank \& Moebus 1987, Proctor \& Fuhrman 1990, Waterbury 1992), although the recent discovery of a bacterium that reaches a length of $600 \mu \mathrm{m}$ (Angert et al. 1993) cautions against belief in rigid size limits for organisms. Even the 'largest' Chlorella viruses 
reported to date (e.g. 200 nm; Van Etten et al. 1991) are considerably smaller than the LVLPs. Proctor \& Fuhrman (1991) analyzed some of these same particulate (bulk trap material and fecal pellets) samples used here in a detailed electron microscopic analysis of viruses. They reported several eukaryotic algal cells containing numerous viruses, but the viruses were small. They also found no recognizable cyanobacteria or Chlorella-like cells infected with viruses. Data on viruses of marine protozoans are notably lacking (e.g. Théodoridès 1989). The best-known protozoan viruses are small (80 $\mathrm{nm}$ or less) and are from non-marine protozoans that are obligatory parasites (Dodds 1983, Wang \& Wang 1991). There is one report of a large (385 nm) icosahedral VLP infecting a freshwater autotrophic dinoflagellate (Sicko-Goad \& Walker 1979). Phaeodarians can consume autotrophic and heterotrophic dinoflagellates (Gowing 1989), and when this occurs, cellular remnants in the form of trichocysts should persist in vacuoles. In the present data set, $<1 \%$ of the vacuoles either with or without LVLPs contained trichocysts, suggesting that dinoflagellates were not a common food item for these phaeodarians and were unlikely to be the source of the LVLPS.

Single LVLPs associated with particulate material or LVLPs suspended in the water could also have been ingested. LVLPs in micrographs of some of the other types of samples (bulk trap material, zooplankton guts, and fecal pellets) are consistent with ingestion of loose LVLPs. These LVLPs occurred as individuals rather than as clusters, and in some cases were in association with minipellets, suggesting that LVLPs exist loose in detrital matrices in the ocean. Further confirmation of this based on a larger sample size is needed, however, because the current data set only contained a few examples of LVLPs from samples of particles. The types of cells that phaeodarians consume are found both suspended in the water and on sinking particulate material; thus phaeodarians may feed on suspended cells (Gowing 1986). Bratbak et al. (1992a) found abundances of LVLPs up to $10^{4} \mathrm{ml}^{-1}$ in coastal waters; no water samples were examined in the present study. It should be emphasized that the presence of LVLPs in food vacuoles with other food materials and cells indicates ingestion of LVLPs during feeding, rather than by engulfment after their random encounter with the phaeodarian through diffusive transport. Diffusive transport is a mechanism recently proposed by Murray \& Jackson (1992) for acquisition of aquatic viruses by particles. Diffusion depends on particle size and is thus less important for LVLPs than for smaller VLPs.

The only other protozoan observed with LVLPs was a specimen of the heliozoan Sticholonche sp. It is also a sarcodine, and it also contained LVLPs in its feeding vacuoles. These LVLPs were $330 \mathrm{~nm}$ in longest dimension, but otherwise similar to the LVLPs from phaeodarians. There was nothing in the heliozoan vacuoles indicating the origin of the LVLPS

To determine the role of phaeodarians in the fate of LVLPs, one needs to know the abundance of the phaeodarians, their feeding and defecation rates, the concentration of LVLPs per phaeodarian, whether the LVLPs are digested or can be released in a viable state, and the concentration of LVLPs suspended in the water and on particulate material. Data on most of these topics are lacking. Abundances of phaeodarians are known from only a few oceanic areas, and these are on the order of tens to thousands $\mathrm{m}^{-3}$. A total cell content of 5861 LVLPS was calculated for the phaeodarian from the Sargasso Sea that was serially sectioned for analysis. Although that is an estimate for 1 organism, an average phaeodarian could contain thousands of LVLPs by the following reasoning. The number of LVLPs in a single section of the Sargasso Sea phaeodarian ranged from 1 to 7 , and the numbers of LVLPs per section in similar-sized phaeodarians that were not serially sectioned ranged from 1 to 21 . It is unlikely that the sections of the other phaeodarians revealed the only LVLPs present; thus the calculation may be a valid estimate for LVLPs contained in phaeodarians from other sites as well. This study also suggests that the abundance of LVLPs varies spatially and/or temporally because the percentage of phaeodarians sectioned that contained any LVLPs ranged from 2 to $45 \%$ over the locations sampled. However, geographic or species differences in phaeodarian feeding behavior cannot be ruled out.

In conclusion, phaeodarians from many depths in many oceans appear to have sampled LVLPs while feeding, indicating that LVLPs are ubiquitous. The unique feeding biology of phaeodarians, including omnivorous generalism and retention of vacuoles in the phaeodium, allowed the prevalence of LVLPs to be noted. The current focus of research on marine viruses began with the recognition of types and abundances of smaller viruses in the ocean and was followed by identification of hosts and determination of the impact of viral infections on carbon dynamics (e.g. Suttle et al. 1990, Bratbak et al. 1992b, Proctor \& Fuhrman 1992). Similar studies are now needed for LVLPs. The widespread occurrence of LVLPs may be further evidence that natural virus assemblages are diverse. If the LVLPs are indeed viruses, the current placement of virioplankton in the femtoplankton 10.02 to $0.2 \mu \mathrm{m}$; Sieburth et al. 1978) will need to be revised. On the other hand, if these particles can be identified as something other than a virus, similar questions can be asked about their role in the sea. 
Acknowledgements. I thank G. Bratbak for suggestions and encouragement, R. T Hinegardner, J. Van Etten, and $M$. Voytek for discussions, encouragement, and reviewing the manuscript, and L. M. Proctor for many helpful suggestions, cautionary advice, and for reviewing the manuscript. I thank A. I. Aronson, M. Brakke, A. Coleman, M. Dalbey, J. A. Dodds, F. A. Eiserling, L. J. Goff, L. Hoffman, J. McN. Sieburth, and B. B. Ward for consultations on the micrographs of LVLPs, M.W. Silver for sharing micrographs, and A. F. Michaels for providing the samples from the Sargasso Sea collected as part of the US JGOFS Bermuda Atlantic Time Series (BATS) samples. The Division of Natural Sciences, UCSC, provided TEM filament time, for which I am grateful I also thank the numerous people who helped on cruises, processed samples in the laboratory, and sectioned the material over the years who are acknowledged in previous publications, and most recently, K. Smith and W. Bentham. This work was supported in part by NSF grants DPP 8715974 to M.M.G. and D. L. Garrison, DPP 8420184 to D. L. Garrison, OCE 8720193 to M.M.G., OCE 8300041 and 8716564 to K.F. Wishner, and OCE 803200,8315059 , and 8600459 to M. W. Silver

\section{LITERATURE CITED}

Angert, E., Clements, K. D., Pace, N. (1993). The largest bacterium. Nature 362: 239-241

Anthony, D. W., Comps, M. (1991). Iridoviridae. In: Adams, J. R., Bonami, J. R. (eds.) Atlas of invertebrate viruses. CRC Press, Boca Raton, p. 55-86

Bergh, O., Borsheim, K. Y., Bratbak, G., Heldal, M. (1989). High abundance of viruses found in aquatic environments. Nature 340:467-468

Borsheim, Y., Bratbak, G., Heldal, M. (1990). Enumeration and biomass estimation of planktonic bacteria and viruses by transmission electron microscopy. Appl. environ. Microbiol. 56: 352-366

Bradley, D. E. (1967). Ultrastructure of bacteriophages and bacteriocins. Bact. Rev. 31:230-314

Bratbak, G., Haslund, O. H., Heldal, M., Naess, A., Roeggen, T. (1992a). Giant marine viruses? Mar. Ecol. Prog. Ser. 85: 201-202

Bratbak, G., Heldal, M., Norland, S., Thingstad, T. F. (1990). Viruses as partners in spring bloom microbial trophodynamics. Appl environ. Microbiol. 56: 1400-1405

Bratbak, G., Heldal, M., Thingstad, T F., Riemann, B., Haslund, O. H. (1992b). Incorporation of viruses into the budget of microbial C-transfer. A first approach. Mar. Ecol. Prog. Ser. 83: 273-280

Cavalier-Smith, T. (1985). Eukaryote gene numbers, non-coding DNA and genome size. In: Cavalier-Smith, T. (ed.) The evolution of genome size. John Wiley and Sons Ltd., New York, p. 69-103

Devauchelle, G., Stoltz, D. B., Darcy-Tripier, F. (1985). Comparative ultrastructure of Iridovividae. In: Willis, D. B. (ed.) Current topics in microbiology and immunology. 116. Iridoviridae. Springer-Verlag, New York, p. 1-21

Doane, F. W., Anderson, N. (1987), Electron microscopy in diagnostic virology. Cambridge University Press, Cambridge

Dodds, J. A. (1979). Viruses of marine algae. Experientia. 35: $440-442$

Dodds, J. A (1983). New viruses of eukaryotic algae and protozoa. In: Matthews, R. E. F. (ed). A critical appraisal of viral taxonomy. Chap. 7 CRC Press, Boca Raton, p. $177-188$
Dodds, J. A., Cole, A. (1980). Microscopy and biology of Uronema gigas, a filamentous eucaryotic green alga, and its associated tailed virus-like particle. Virology 100: $156-165$

Frank, H., Moebus, K. (1987). An electron microscopic study of bacteriophages from manine waters. Helgoländer. Meeresunters. 41: 385-414

Gowing. M. M. (1986). Trophic biology of phaeodarians and flux of living radiolarians in the upper $2000 \mathrm{~m}$ of the North Pacific central gyre. Deep Sea Res. 655-674

Gowing, M. M. (1989). Abundance and feeding ecology of Antarctic phaeodarian radiolarians. Mar. Biol. 103: $107-118$

Gowing, M. M. (1993). Seasonal radiolarian fluxes at the VERTEX North Pacific time-series site. Deep Sea Res. 40: $517-545$

Gowing, M. M., Coale, S. L. (1989). Fluxes of living radiolarians and their skeletons along a northeast Pacific transect from coastal upwelling to open ocean waters. Deep Sea Res. 36: 561-576

Gowing, M. M., Garrison, D. L. (1992). Abundance and feeding ecology of larger protozooplankton in the ice-edge zone of the Weddell and Scotia Seas during the austral winter. Deep Sea Res. 39: 893-919

Gowing, M. M., Silver, M. W. (1983), Origins and microenvironments of bacteria mediating fecal pellet decomposition in the sea. Mar. Biol. 73: 7-16

Gowing, M. M., Silver, M. W. (1985). Minipellets: a new and abundant size class of marine fecal pellets. J. mar. Res. 43: $395-418$

Gowing, M. M., Wishner, K. F. (1986). Trophic relationships of deep-sea calanoid copepods from the benthic boundary layer of the Santa Catalina Basin, Ca. Deep Sea Res. 33: 939-961

Gowing, M. M., Wishner, K. F. (1992). Feeding ecology of benthopelagic zooplankton on an eastern tropical Pacific seamount. Mar. Biol. 112: 451-467

Gromov, B. V., Mamkaeva, K. A. (1981). A virus infection in the synchronized population of the Chlorococcum minutum zoospores. Arch. Hydrobiol. Suppl. 60 (3): 252-259

Herdman, M. (1985). The evolution of bacterial genomes In: Cavalier-Smith, $\mathrm{T}$ (ed.) The evolution of genome size John Wiley \& Sons Ltd, New York, p. 37-68

Hinegardner, R. T (1976). Evolution of genome size. In Ayala, F. J. (ed.) Molecular evolution. Sinauer Associates, Inc., Sunderland, MA, p. 179-199

Hoffman, L. R., Stanker, L. H. (1976). Virus-like particles in the green alga Cylindrocapsa. Can. J. Bot. 54 $2827-2841$

Knauer, G. A., Martin, J. H., Bruland, K. W. (1979). Fluxes of particulate carbon, nitrogen, and phosphorus in the upper water column of the northeast Pacific. Deep Sea Res. 26 97-108

Martin, J H., Knauer, G. A., Karl, D. M., Broenkow, W. W (1987). VERTEX: carbon cycling in the northeast Pacific Deep Sea Res. 34: 267-285

Mattern, C. F. T., Hruska, J. F., Diamond, L. S. (1974). Viruses of Entamoeba histolytica. V. Ultrastructure of the polyhedral virus $V_{301}$. J. Virol. 13: 247-249

Murray, A. G., Jackson, G. A. (1992). Viral dynamics: a model of the effects of size. shape, motion and abundance of single-celled planktonic organisms and other particles. Mar. Ecol. Prog. Ser. 89: 103-116

Nöthig, E.-M., Gowing, M. M. (1991). Late winter abundance and distribution of phaeodarian radiolarians, other large protozooplankton, and copepod nauplii in the Weddell Sea, Antarctica. Mar. Biol. 111: 473-484 
Palmer, E. L., Martin, M. L. (1988). Electron microscopy in viral diagnosis. CRC Press, Boca Raton

Plumb, J. A. (1993). Viral diseases of marine fish. In: Couch, J. A., Fournie, J. W. (eds.) Pathobiology of marine and estuarine organisms. CRC Press, Boca Raton, p. 25-52

Pope, L., Rode, L. J. (1969). Spore fine structure in Clostridium cochlearium. J. Bacteriol. 100: 994-1001

Proctor, L. M., Fuhrman, J. A. (1990). Viral mortality of marine bacteria and cyanobacteria. Nature 343: 60-62

Proctor, L. M., Fuhrman, J. A. (1991). Roles of viral infection in organic particle flux. Mar. Ecol. Prog. Ser. 69: 133-142

Proctor, L. M., Fuhrman, J. A. (1992). Mortality of bacteria in response to enrichments of the virus size fraction from seawater. Mar. Ecol. Prog. Ser. 87: 283-293

Reanney, D. C., Ackermann, H.-W. (1982). Comparative biology and evolution of bacteriophages. In: Lauffer, M. A., Bang, F. B., Maramorosh, K., Smith, K. M. (eds.) Advances in virus research. Academic Press, New York, p. 205-280

Reisser, W. (1993). Viruses and virus-like particles of freshwater and marine eukaryotic algae - a review. Arch. Protistenkd. 143: 257-265

Sherman, L. A., Brown, R. M. Jr (1978). Cyanophages and viruses of eukaryotic algae. In: Fraenkel-Conrat, $H$. Wagner, R. R. (eds.) Comprehensive virology. Plenum, New York, p. 145-234

Sicko-Goad, L., Walker, G. (1979). Viroplasm and large viruslike particles in the dinoflagellate Gymnodinium uberrimum. Protoplasma. 99: 203-210

Sieburth, J. McN. (1979). Sea microbes. Oxford University Press, London

Sieburth, J. McN., Smetacek, V., Lenz, J. (1978). Pelagic ecosystem structure: heterotrophic compartments of the plankton and their relationship to plankton size fractions. Limnol. Oceanogr. 23: 1256-1263.

Silver, M. W., Gowing, M. M. (1991). The particle flux: origins and biological components. Prog. Oceanogr. 26: 75-113

This article was submitted to the editor
Silver, M. W., Gowing, M. M., Davoll P. J. (1987). The association of photosynthetic picoplankton and ultraplankton with pelagic detritus through the water column $(0-2000$ m). Can. Bull. Fish. Aquat. Sci. 214: 311-341

Suttle, C. A., Chan, A. M., Cottrell, M. T. (1990). Infection of phytoplankton by viruses and reduction of primary productivity. Nature 347: 467-469

Swale, E. M. F., Belcher, J. H. (1973). A light and electron microscope study of the colorless flagellate Aulacomonas Skuja. Arch. Mikrobiol. 92: 91-103

Swanberg, N. R., Bennett, P., Lindsey, J. L., Anderson, O. R. (1986). The biology of a coelodendrid: a mesopelagic phaeodarian radiolarian. Deep Sea Res. 33: 15-25.

Takagi, A., Kawata, T., Yamamoto, S. (1960). Electron micoscope studies on ultrathin sections of spores of the Clostridium group, with special reference to the sporulation and germination process. J. Bacteriol. 80: 37-46

Théodonidès, J. (1989). Parasitology of marine zooplankton In: Blaxter, J. H. S., Southward, A. C. (eds.) Advances in marine biology. Academic Press, New York, p. 118-177

Tinsley, T. W., Harrap, K. A. (1978). Viruses of invertebrates. In: Fraenkel-Conrat, H., Wagner, R. R. (eds.) Comprehensive virology. Plenum, New York, p. 1-101

Van Etten, J. L., Lane, L. C., Meints, R. H. (1991). Viruses and viruslike particles of eukaryotic algae. Microbiol. Rev. 55: $586-620$

Viñuela, E. (1985). African swine fever virus. In: Willis, D. B. (ed.) Current topics in microbiology and immunology. 116. Iridoviridae. Springer-Verlag, New York, p. 151-170

Wang, A. L., Wang, C. C. (1991). Viruses of the protozoa. A. Rev. Microbiol 45: 251-263.

Waterbury, J. B. (1992). Viruses of marine bacteria. Oceanus 35: $107-108$

Wommack, K. E., Hill, R. T., Kessel, M., Russek-Cohen, E., Colwell, R. R. (1992). Distribution of viruses in the Chesapeake Bay. Appl. environ. Microbiol. 58: 2965-2970

Manuscript first received: April 30, 1993

Revised version accepted: July 20, 1993 